\title{
The Emperor of the Zoom: Aphra Behn and the Many Challenges of Zoom Productions
}

\author{
Anna Mikyšková, Klára Škrobánková
}

This article was supported by the Czech Science Foundation project GA19-07494S. English Theatre Culture 1660-1737

"On this paltry stage of Zoom, we here present the Emperor of the Moon."

In 2020, theatres faced challenges posed by the worldwide COVID-19 pandemic, which forced the cultural sphere to search for new ways of reaching their audiences. Video conferencing platforms, together with the streaming platforms (such as NT Live or the new Czech provider Dramox), became the most important additions to the theatrical toolboxes. As the national or regional lockdowns continued well into the second half of the 2020 and beyond, many theatres turned to organising video "conferences", which were to substitute standard theatre productions, as well as streams of prerecorded or live performances. The video conferencing platform Zoom enabled theatre makers to experiment with various forms of staging productions in the digital space. Some decided to adapt already existing plays to the Zoom format, choosing plays heavily text-based, which could be performed in the actors' own homes (such was the case of Abbey Theatre's This Beautiful Virtual Village, where the audience watches the characters discuss social and political topics), others decided to use Zoom in order to directly communicate with their audiences, incorporating their immediate reactions into the live performance (as the creators of the Czech/German production of Spielraum Kollektiv's Zbytečnosti/ Überflüssigkeiten chose to). Although these attempts did function as legitimate theatrical pieces in their own right, the sense of provisionality and a certain 2D experience prevailed. The November virtual premiere of R/18 Collective's production of The Emperor of the Moon, however, took advantage of the potential of Zoom in an original way, emphasizing the usefulness of the platform even for the postpandemic future.

The Emperor of the Moon, a Restoration farce by the English author Aphra Behn, was produced by the $\mathrm{R} / 18$ Collective and adapted for Zoom by Misty G. Anderson, Charlotte Munson, and Charles Pasternak. ${ }^{1}$ Its Zoom premiere took place on 22 November 2020 with 180 people signing up in advance for the event. As Behn's farce is not often staged (in Britain, for instance, it was scarcely staged throughout the 20th century, and none of Behn's plays have ever been produced in the Czech Republic) and its humour relies heavily on physical comedy, the choice of such a text to be performed in the digital space with actors confined to the isolation of their own homes was certainly unusual.

1 See also Misty G. Anderson's reflection on the experience in this volume. 
In many ways, the two-hour production of The Emperor of the Moon introduced changes typical of staging an old text for modern audiences when it eclectically mixed techniques and elements of modern and historical theatre - it gently referenced contemporary political situation in the United States, employed genderblind casting, and the music featured Queen's "Bohemian Rhapsody", tunes by Gilbert and Sullivan as well as the songs present in Behn's farce. Nevertheless, the adaptors were also confronted with some challenges and shortcomings of the Zoom environment, which they strived to overcome or even use to their advantage.

The lack of a concrete visual setting lent the performance certain spacelessness, which might be perceived as one of the (understandable) drawbacks of Zoom. The creators of the Emperor on the Zoom therefore introduced the character of a Narrator, who, by reading Behn's stage directions, helped create the fictional world of the play. However, such an approach also emphasized the universality of the performed piece. Even though the spectators were told that the story takes place in Naples, the staging did not fix the location visually, and the spectators were free to imagine any place they liked, opening the door to any possible interpretation. This does not mean that one cannot utilise the Zoom stage space to carry certain meaning. Mise-en-scène can still be created in the "space" of a small rectangle on the screen. The crew of The Emperor of the Moon used a number of film techniques, such as close-ups (for asides), works with the depth of the "stage" and also experiments with the light, combining the light of the room, screen and candles to distin- guish between the moods of the scene and between day and night.

Moreover, the visual effects facilitated by Zoom's sharing function were originally deployed in the scenes in which Dr Baliardo looks through his (in this production her) telescope and is deceived to see the lunar empire. What was in the original play achieved by a trick of inserting painted glasses onto the lenses of the doctor's telescope was in this production solved by images that were screen-shared with every member of the audience, playing thus with the spectator's gaze. The amateur collage of the actors' photos with baroque-like celestial landscape and chariots was indeed hilarious, and the several scenes taken from Georges Méliès's film A Trip to the Moon (1902), which famously employed theatrical techniques, also helped to reinforce the lunar theme of the play, with Méliès's stationary camera working as a perfect simulation of the telescope view. At the same time, the shared visual content in many ways evoked the Restoration theatre aesthetics. The collage of actors and the layers of celestial background reminded one of the interaction of performers and flying machines from Behn's time, and one could notice the similarity of Méliès's naive clouds to the Restoration equivalent of the set piece. As a result, the screen-shared images were not only entertaining, they also invoked the "old-timey" feeling of basic visual tricks of the seventeenth-century English stage.

One can wonder what kind of theatre is taking place on Zoom. When asked in the post-production discussion to comment on his acting experience, actor Charles Pasternak (Harlequin) pointed out that since "we are telling oral stories [...] it needs to be closer to radio theatre with 
some sort of live effects". The similarity to radio plays is, of course, striking, and the production makers took advantage of that when they, except for occasional omissions, preserved the entire text of Behn's farce. Zoom's focus on the spoken word was further enhanced by the close-ups of actors' faces, which, as Al Coppola mentioned in the intermission interview, also partly helped substitute for the lost physicality of the farce. However, the physicality of Harlequin and Scaramouch's sketches was not lost entirely, as the techniques of radio drama seemed to have been combined with that of puppetry. The fact that Pasternak (Harlequin) and Charlotte Munson (Scaramouch) shared one Zoom window allowed them to act in a kind of a puppet stage frame, and scenes such as their comical fight in scene 1.2, in which the actors used table knives instead of swords, and another fight in scene 3.2 staged as a slowmotion slapstick brawl, were reminiscent of the violent Punch and Judy shows of the post-Restoration periods. Although the reliance on the spoken word was predominant, surprisingly a great deal of the original physical comedy of Behn's farce was thus retained through the use of simple props, clever minimalist blocking and a vigorous work with facial expressions.

As far as the audience is concerned, performers may find Zoom very challenging as they often cannot have a proper response from their spectators, yet they know that someone is watching. The director, on the other hand, can work with the viewers' attention in a more conscious way. It is much easier to direct their attention to certain aspects of the performance when using Zoom and therefore combining the techniques of both theatre and film. This has certain benefits for the audience as well - name tags embedded at the bottom of the frames help with orientation among the many characters, with the gallery view always putting the same characters in the same place on the screen.

Even though the digital space of Zoom might seem to intensify the isolation of both performers and spectators, the Emperor provided the audience with a possibility of deeper connection exceeding the passive watching of the Zoom action. The chat, a common feature of Zoom, became a space where spectators could share their impressions about the on-going action, but also where one could start a discussion with the creators of the production during the performance itself. The spectators could also chat with each other, which alters the theatrical conventions as the interaction between audience members is usually undesirable. Emotions are substituted with emoticons, which are not natural and immediate but can still provide feedback to the actors after the performance. Even though Pasternak was right in saying that "Zoom cannot replicate the intimacy of being in a theatre", the chatroom provided the audience at least with the possibility of creating a live community united by the on-going mutual experience.

One specific feature of the Zoom production of the Emperor was the community which it aimed to create. As Misty Anderson put it, "the first production of the R/18 Collective [was organized by] a group of scholars who $[\ldots]$ try to create the conditions that bring scholars and theatre makers together in the hopes that we'll get to see more of these plays in our lifetime". Indeed, the production has attracted many scholars from the field of Restoration and eighteenth-century studies who enjoyed the experiment and, judged by their chat 
discussion about other "understaged" dramatic pieces they would love to see performed this way, the potential of Zoom for such texts is significant. The collaboration of scholars and actors on reconstructing old English drama is essential, because the former provide historical knowledge and the latter practical theatre experience. The Emperor has demonstrated that Zoom, with its prominent focus on the spoken word, can facilitate such collaboration in the times of social distancing. Yet another great advantage of Zoom is the fact that the considerable cost of putting on a theatre production, which often limits the number of Restoration and eighteenthcentury texts professionally staged, can be avoided. Apart from the general conclusion that Zoom is indeed a productive platform for socially distanced theatre, the first Zoom production by $\mathrm{R} / 18 \mathrm{Col}-$ lective has proved that such projects can also deepen our understanding of theatre from historically distanced times.
As the production of The Emperor of the Moon has demonstrated, Zoom might be purposefully utilized as a valuable theatrical instrument, not as a mere contingency tool used to bridge the theatrical void in the times of the Covid-19 crisis. One of the most important assets is Zoom's ability to revive the here-and-now quality of the theatrical experience, which we miss in recorded performances. Its didactical level and cost effectiveness opens new possibilities for researching (not only) Restoration theatre in performance. Such approach might, to a considerable extent, reveal the qualities of the text, which would otherwise be impossible to discover only by close reading and academic research. Zoom will certainly never replace live theatre but it should not be forgotten as soon as theatres reopen as it has the potential to facilitate a discussion between academics and theatre makers about the limits of theatre and dramatic literature research. 